\title{
SEED SIZE, NITROGEN SUPPLY, AND GROWTH RATE AFFECT TREE SEEDLING SURVIVAL IN DEEP SHADE
}

\author{
Michael B. Walters ${ }^{1}$ And Peter B. Reich ${ }^{2}$ \\ ${ }^{1}$ Department of Forestry, Michigan State University, East Lansing, Michigan 48824 USA \\ ${ }^{2}$ Department of Forest Resources, University of Minnesota, St. Paul, Minnesota 55108 USA
}

\begin{abstract}
Species differences in seedling survival in deeply shaded understories (i.e., shade tolerance) may depend on both seed size and growth rates, but their relative contributions to survival and how they change with time and with variation in light and belowground resource availability is unknown. With a greenhouse experiment we investigated these relationships by examining responses of growth, growth-related morphology, survival, and their interrelationships to a range of nitrogen $\left(3.4 \times 10^{-9}-3.4 \times 10^{-3} \mathrm{~mol} / \mathrm{L} \mathrm{N}\right.$ fertilizer solutions) and low light (0.6-7.3\% of open sky) availabilities for young seedlings of 10 North American tree species that vary in observational shade tolerance rankings and seed size (Populus tremuloides, Betula papyrifera, Betula alleghaniensis, Acer saccharum, Larix laricina, Pinus banksiana, Pinus resinosa, Pinus strobus, Picea mariana, and Abies balsamea).

Within all species, relative growth rate (RGR) and survival increased with light. RGR and survival also increased with $\mathrm{N}$ supply but only at the two highest light levels, and then only for the shade-intolerant, broad-leaved Populus and Betula spp.. In every species, survival was positively related to RGR. Moreover, each species differed in the relationship of survival to RGR, and these differences were related to seed mass: at any given RGR, large-seeded, shade-tolerant species had higher survival than smaller-seeded, intolerant ones.
\end{abstract}

Across species, in most light and $\mathrm{N}$ treatments, seed mass was positively related to young seedling survival, but RGR was not. In very low light the relative benefits of greater seed mass to survival were temporary. As seedlings aged, interspecific mortality rates became more dependent on observational shade tolerance rankings than on seed size, but mortality was still unrelated to RGR.

Our results indicate potentially important interactions among light, $\mathrm{N}$, and species that could influence regeneration dynamics. For young seedlings in deeply shaded microsites, $\mathrm{N}$ supply does not matter, and only shade-tolerant species survive due, in part, to large seeds and physiological traits other than RGR. In moderate shade, RGR is greater, and survival is high for all species, except that small-seeded, broad-leaved, intolerant species have low survival and RGR at low $\mathrm{N}$ supply. This suggests that broad-leaved shadeintolerant species compete more effectively in moderate shade on richer soils than on poorer soils. Although we found that both seed mass and vegetative physiology influenced survival in shade, they did not covary tightly, suggesting that they are under somewhat separate selection pressures.

Key words: $\quad$ biomass allocation; cold-temperate forests; low light; nitrogen availability; relative growth rate (RGR); seed size; shade tolerance; survival; tree seedlings.

\section{INTRODUCTION}

Among the traits underlying the abilities of some tree species to maintain populations of seedlings and saplings in forest understories, enhanced low-light survival (i.e., shade tolerance) is considered key (Baker 1945, Pacala et al. 1996). For young seedlings, two traits long thought to contribute to low-light survival are a large seed (Salisbury 1942, Grime and Jeffrey 1965, Foster and Janson 1985, Foster 1986) and enhanced low-light growth through particular expressions of physiological and morphological characteristics (Bjorkman 1981, Givnish 1988, Metcalf and Grubb

Manuscript received 9 February 1998; revised 22 April 1999; accepted 26 April 1999; final version received 16 June 1999.
1995, Barnes et al. 1998). Enhanced low light growth as a component of shade adaptation seems logical since in the growth-limiting, low-light environments of closed understories ( $\sim 1-3 \%$ of open sky light; Canham et al. 1990, Ellsworth and Reich 1992), adaptations enhancing growth could confer competitive advantages.

Until recently, it was generally accepted that enhanced low-light growth is an important basis of shade tolerance; however, several multiple-species studies have cast doubt on this notion. These studies have shown that relative growth rate (RGR) in low light is low but generally similar in tolerant and intolerant species (Baker 1945, Osunkoya et al. 1994, Grubb et al. 1996), although higher RGRs for intolerant species 
have also been reported (Kitajima 1994, Veenendaal et al. 1996). These studies have also shown that leaf area ratio (LAR: leaf area $\left[\mathrm{cm}^{2}\right] /$ plant mass $[\mathrm{g}]$ ), a strong determinant of RGR in high and moderately low light (Lambers and Poorter 1992, Reich et al. 1992, Walters et al. 1993a, Poorter and Van Der Werf 1998), is generally greater in low light for intolerant than for tolerant species (Kitajima 1994, Pompa and Bongers 1988, Osunkoya et al. 1994, Grubb et al. 1996, Veenendaal et al. 1996, Reich et al. 1998). These patterns suggest that, at all light levels, intolerant species maintain a greater growth potential (i.e., higher LAR) than tolerant species, but this growth potential may be unrealized in conditions of severe light limitations.

Seed size is also considered an important component of shade tolerance, but conflicting results have cast doubt on the generality of the relationship. Seed mass has been positively related to short-term survival in shade in species contrasts that were both phylogenetically broad (Grime and Jeffrey 1965, Hutchinson 1967, Leishman and Westoby 1994) and narrow (Saverimuttu and Westoby 1996). However, other studies have found weak relationships between seed size and low-light survival in both phylogenetically broad (Augspurger 1984) and narrow (Grubb and Metcalf 1996) contrasts.

A larger seed, with greater energy reserves, could help confer shade tolerance by: 1) allowing radicle penetration to the mineral soil through the deep litter layers that are often found in forest understories (Marquis 1975, Molofsky and Augspurger 1992); 2) allowing the initial establishment of a larger germinant, which would make it less susceptible to smothering by leaf litter and could enable competition with short-statured vegetation to be won (Grime and Jeffrey 1965); 3) providing reserves for the compensation of leaf loss from damaging agents (Foster 1986, Armstrong and Westoby 1993), and/or; 4) delaying the onset of carbon starvation and death in low light understories, thus increasing the likelihood of exposure to a canopy gap before death (Leishman and Westoby 1994, Saverimuttu and Westoby 1996). Maximizing RGR could also directly or indirectly enhance low-light survival. Greater RGR would allow seedlings to escape the greater risks of small size quickly and out-compete slower growing neighbors. In addition, greater RGR may reflect an improved overall energy status for coping with pathogens, resource shortfalls, and other agents of mortality (Augspurger 1984). Conversely, traits enhancing low-light RGR, such as greater allocation to leaf area, may occur at the expense of allocation to storage and protection and thus could compromise low-light survival (Chapin et al. 1990, Kobe 1997). Although enhanced growth and seed mass may both contribute to survival in low light, their combined effects on lowlight survival may be further complicated by the negative relationship generally reported between seed size and RGR in both high and moderately low light (Ship- ley and Peters 1990, Maranon and Grubb 1993, Swanborough and Westoby 1996, Reich et al. 1998).

The relative contributions of seed mass and RGR to survival may depend on seedling age and resource availability. For example, in contrast to the temporary benefits of the energy stored in a large seed (Hutchinson 1967, Leishman and Westoby 1994), the benefits of enhanced low-light RGR would be expected to be longer term, suggesting that the relationship of RGR and seed size to seedling survival in deep shade may change with seedling age. At present, evidence for positive RGR vs. survival relationships across species is mixed. For example at similar light levels of $\sim 2 \%$ of opensky light, Walters and Reich (1996) report a positive RGR vs. survival relationship across species, whereas Kitajima (1994) reports a negative relationship. In contrast to mixed interspecies trends, within species, positive low-light growth vs. survival relationships have generally been reported for tree seedlings (Walters and Reich 1996) and saplings (Kobe et al. 1995, Kobe 1996, Kobe and Coates 1997). Furthermore, growth rates in low light have been found to be sensitive to small differences in light (Pompa and Bongers 1988, Pacala et al. 1994, Metcalf and Grubb 1995, Grubb and Metcalf 1996, Walters and Reich 1996), and in some cases, to nutrients and water (Peace and Grubb 1982, Walters and Reich 1997, Coombs and Grubb 1998, but not in others Steinbauer 1932, Phares 1971, Latham 1992, Canham et al. 1996, Grubb et al. 1996, Pacala et al. 1996, Walters and Reich 1996). Thus, slightly higher light and belowground resource availability could increase survival by increasing growth. Furthermore, species may differ in their growth and survival responses to covariation in light and belowground resources. These differences, if they exist, may underlie variation in shade tolerance, geographically and across species.

In this study we examined seed size and RGR as correlates of survival over a range of low light and nitrogen (N) availabilities for young seedling of ten tree species that collectively span a broad range of observationally based shade tolerance classifications. Nitrogen was chosen because it is the most common limiting nutrient in temperate forests (Cole 1981). Given what is known, we expected that tolerant and intolerant species would have similar and low RGR in low light, but that larger-seeded and/or more shadetolerant species would have greater short-term survival. We also expected that, as light and $\mathrm{N}$ availabilities increase, RGR and survival would increase for all species, but due to greater growth potential, RGR and survival would increase more for small-seeded intolerant species such that differences in seed size become less important to differences in survival among species. Furthermore, we hypothesized that seed size would largely determine survival for very young seedlings, but that RGR would become more important with time. Our questions were: 
TABLE 1. Study species, seed mass $(\mathrm{mg})$, shade tolerance category, shade tolerance rank (most tolerant $=1)$, life form, and high light relative growth rate $\left(\mathrm{RGR}, \mathrm{mg} \cdot \mathrm{g}^{-1} \cdot \mathrm{day}^{-1}\right)$.

\begin{tabular}{|c|c|c|c|c|c|}
\hline Species & $\begin{array}{l}\text { Seed } \\
\text { mass }\end{array}$ & $\begin{array}{l}\text { Shade tolerance } \\
\text { category }\end{array}$ & $\begin{array}{l}\text { Shade } \\
\text { tolerance } \\
\text { rank }\end{array}$ & Life form & $\begin{array}{l}\text { High } \\
\text { light } \\
\text { RGR }\end{array}$ \\
\hline Populus tremuloides & 0.1 & very intolerant & 8 & deciduous broadleaved & 184 \\
\hline Larix laricina & 1.0 & very intolerant/intolerant & 7 & deciduous conifer & 87.5 \\
\hline Pinus banksiana & 2.8 & intolerant/very intolerant & 6 & evergreen conifer & 56 \\
\hline Betula papyrifera & 0.2 & intolerant/very intolerant & 6 & deciduous broadleaved & 136 \\
\hline Pinus resinosa & 5.8 & intolerant & 5 & evergreen conifer & \\
\hline Betula alleghaniensis & 0.5 & intermediate & 4 & deciduous broadleaved & 115 \\
\hline Рinu strobus & 17.2 & intermediate/tolerant & 3 & evergreen conifer & 47 \\
\hline Picea mariana & 0.7 & tolerant/intermediate & 2 & evergreen conifer & 72 \\
\hline Acer saccharum & 44.6 & very tolerant & 1 & deciduous broadleaved & 56 \\
\hline Abies balsamea & 3.2 & very tolerant & 1 & evergreen conifer & \\
\hline
\end{tabular}

Notes: Mean seed mass was determined from the mass of 201 - to 2-d-old germinants. Shade tolerance categories are a composite of those reported by Baker (1949), Burns and Honkala (1990), and Barnes and Wagner (1996). These categories were then used to assign numerical shade tolerance rankings (see Methods for complete details). High light RGR are for young first-year seedlings from Walters et al. 1993a and Reich et al. 1998.

1) Among the study species, what are the relative contributions of seed size and growth rate in determining variation in survival, and how do these patterns relate to existing notions of shade adaptation and shade tolerance classifications?

2) How do light and $\mathrm{N}$ supply interact in affecting growth and survival within and among species?

To answer these questions we used a factorial greenhouse experiment with four low light levels, three $\mathrm{N}$ fertilization treatments, and first-year seedlings of ten boreal and cold-temperate tree species common to central North America. Light and $\mathrm{N}$ treatments were designed to generate variation in growth and survival and to reflect the range of availabilities that seedlings of these species could experience beneath closed canopy forests. With weekly censusing of mortality to $120 \mathrm{~d}$ total age, coupled with periodic harvests for determining growth and growth related morphology, we developed survivorship curves for species $\times$ light $\times \mathrm{N}$ treatments and evaluated interrelationships of survival parameters, species shade tolerance rankings, growth, and growth related morphology.

\section{Methods}

\section{Study species}

We studied 10 species common in the broad ecotone between the boreal and cold-temperate forests of central and eastern North America. The species differ in seed mass, ecological niche, leaf phenology, and high light growth rates (Table 1). The seeds used in the experiment were all from wild sources in central Minnesota and northern Wisconsin $\left(\sim 47^{\circ} \mathrm{N}\right)$. We developed shade tolerance rankings as a composite of the rankings reported by Baker (1949), Burns and Honkala (1990), and Barnes and Wagner (1996). All three publications included the same five tolerance categories: very intolerant, intolerant, intermediate, tolerant, and very tolerant. For each species, the three publications never reported more than two tolerance categories.
When two categories were reported, the category reported twice was listed first in our composite shade tolerance categories and it was used as a weighting in our numerical shade tolerance rankings (Table 1).

\section{Growing conditions and experimental design}

Seeds were germinated in bench-top trays filled with sand or wet paper towels beneath $50 \%$ neutral density shade cloth in a temperature-controlled greenhouse at the University of Minnesota, St. Paul, Minnesota, USA in mid-February 1994. Single seedlings $(<4 \mathrm{~d}$ following radicle emergence) were transferred to $2 \mathrm{~cm}$ top width $\times 15 \mathrm{~cm}$ depth plastic pots filled with washed silica sand and placed into shade houses $(1.6 \mathrm{~m} \times 1.6$ $\mathrm{m} \times 0.8 \mathrm{~m}$ high) in the same greenhouse. Shade houses were covered with one or two layers of neutral density woven polypropylene shade cloth (Carlin Co., Milwaukee, Wisconsin, USA) to produce $1,2,4$, and $8 \%$ light transmittance treatments. Because the experiment started in mid-February, we extended day length with sodium halide lamps positioned above each shade house. Lamps were on from 1500 to 2200 local time for the duration of the experiment. We monitored photosynthetically active photon flux density nearly continuously over the experiment with calibrated galium arsenide photodiodes or quantum sensors (LI-COR Inc., Lincoln, Nebraska, USA) placed in the center of each shade house at seedling height and attached to data loggers (LI-COR Inc.). Another light sensor was placed outside, on top of the greenhouse. The light measurements indicated that the 1, 2, 4, and $8 \%$ light transmittance treatments resulted in mean percentages $( \pm \mathrm{SE})$ of $0.62 \pm 0.03,1.45 \pm 0.1,2.77 \pm 0.15$, and $7.34 \pm 0.48 \%$ respectively of open-sky light outside the greenhouse. Mean daily total photon flux density outside the greenhouse was $37.75 \mathrm{~mol} \cdot \mathrm{m}^{-2} \cdot$ day $^{-1}$. Our experimental light levels were representative of the range of light levels found in closed forest understories 
of cold temperate North American forests (Canham et al. 1990, Walters and Reich 1997).

Our N treatments were $3.4 \times 10^{-3} \mathrm{~mol} / \mathrm{L}, 3.4 \times 10^{-6}$ $\mathrm{mol} / \mathrm{L}$, and $3.4 \times 10^{-9} \mathrm{~mol} / \mathrm{L}$. Nitrogen was supplied as $\mathrm{NH}_{4}{ }^{+}$and $\mathrm{NO}_{3}{ }^{-}$in equal amounts in a modified Hoagland's solution, where total ion concentration was balanced with $\mathrm{KCl}$. Nutrient solutions were supplied daily. Pots were flushed with distilled water twice weekly to prevent the accumulation of nutrient salts. The lowest $\mathrm{N}$ treatment was chosen to approximate severely limiting conditions that seedlings may encounter on some regeneration substrates. Nitrogen solution at $3.4 \times 10^{-6} \mathrm{~mol} / \mathrm{L}$ is of the same magnitude as the $\mathrm{KCl}$-extractable standing pool sizes found in some northern temperate forests (M. B. Walters, unpublished data; M. Tobin and P. B. Reich, unpublished data), and $3.4 \times 10^{-3} \mathrm{~mol} / \mathrm{L} \mathrm{N}$ represents an abundant supply.

Three replicates (shade houses) of each shade treatment were arranged in blocks parallel to an environmental gradient (light and temperature) from the south wall of the greenhouse (block 1) to the middle of the greenhouse (block 3). Between 18 and 20 seedlings were allocated to each block $\times \mathrm{N}$ treatment $\times$ light treatment $\times$ species resulting in a total of $\sim 6600$ seedlings. Seedlings were rotated within shade houses several times during the course of the experiment from mid-February to late June. The ten species, four light treatments, and three $\mathrm{N}$ treatments comprised a complete factorial design as a split plot, with species and $\mathrm{N}$ treatments as subplots within light environment whole plots.

\section{Measurements}

Mortality was monitored for each individual on a weekly basis for the first 16 wk of the experiment. Agents of mortality according to the following general categories were recorded for each individual: damping off (Fusarium), mechanical damage (e.g., broken or uprooted), and other (e.g., carbon starvation). Seedlings were harvested four times during the course of the experiment, with harvest age varying slightly among species, but not among treatments within species. Harvests, seedling ages from germination, and number harvested were: 1) initial germinant mass just prior to placement into the treatments, 1-3 d old, 10 per species; 2) first harvest, 2-4 wk old, 2 per treatment $\times$ block combination; 3) second harvest, 8-9 wk old, 2 per treatment $\times$ block combination, and; 4) third (final) harvest, 19-20 wk old, all surviving seedlings. In some treatment combinations (e.g., P. tremuloides in $0.6 \%$ light), complete mortality early in the experiment resulted in missing intermediate and/or final harvests. For all species, initial germinant mass and seed mass were similar such that $\ln$ (seed mass) and ln(germinant mass) were strongly correlated across species $(r=0.94, P<0.0001)$. Thus, hereafter, initial germinant mass will be referred to as seed mass.
The mass of all harvested seedlings was measured after drying in a forced-air oven at $70^{\circ} \mathrm{C}$. In addition, for all individuals in intermediate harvests and at least two per treatment $\times$ block combinations for the final harvest, we split seedlings into root, stem, and leaf fractions prior to drying, and measured projected leaf area with an image analysis system (Decagon Devices, Pullman, Washington, USA). We then dried and measured mass for each fraction as described above. From mass and leaf area data we calculated the following morphological parameters: leaf mass ratio (leaf mass $[\mathrm{g}] /$ plant mass $[\mathrm{g}]$ ), stem mass ratio (stem mass $[\mathrm{g}] /$ plant $[\mathrm{g}]$ ), root mass ratio (root mass $[\mathrm{g}] /$ plant mass $[\mathrm{g}]$ ), specific leaf area (fresh leaf area $\left[\mathrm{cm}^{2}\right] /$ dry leaf mass $[\mathrm{g}]$ ), and leaf area ratio (fresh leaf area $\left[\mathrm{cm}^{2}\right] /$ plant mass [g]). Average relative growth rate $\left(\mathrm{mg} \cdot \mathrm{g}^{-1} \cdot \mathrm{d}^{-1}\right)$ was estimated between individual harvests as: $(\ln [$ mass harvest $a+1]-\ln$ [mass harvest a])/ $\mathrm{d}^{-1}$.

\section{Analysis}

Effects of N, light and species treatments, blocks, and their interactions on plant mass and morphological characteristics were analyzed for harvest two and three separately with ANOVA (JMP, SAS Institute, Cary, North Carolina, USA). Our analyses focus on the second and third harvests since insufficient time had elapsed by the first harvest for treatment effects to emerge. We performed these analyses for harvests separately rather than include time as a factor in the ANOVA since there were several missing cells by harvest two and many more by final harvest due to high mortality in some of the treatments which would have resulted in an unbalanced ANOVA. In order to achieve balance among cells, some treatments had to be excluded from the ANOVA. For example, for plant mass, all data for $P$. tremuloides, B. papyrifera, and B. alleghaniensis were excluded from the harvest two ANOVA, and the same three species plus all species in $0.6 \%$ light were excluded from the final harvest ANOVA. $F$ ratios were calculated for most effects with the residual error term and the four-way interaction term (light $\times \mathrm{N}$ treatment $\times$ species $\times$ block) pooled, since four way interactions are difficult to interpret and were never significant (Neter and Wasserman 1974). F ratios for light and block effects were calculated with the light $\times$ block interaction term.

We analyzed for main treatment effects and their interactions on survival with proportional hazards modeling (Fox 1993) using JMP. Seedlings that were harvested or that died from breakage, uprooting, or other mechanical damage were "right censored" in the data set. Right censoring indicates that a seedling was alive at the time that it was removed and is not considered killed by the experimental treatments in the analysis. We chose semiparametric proportional hazards modeling over parametric approaches since preliminary analyses of Weibull, and $\log -\log$ transfor- 
mations of product limit (Kaplan-Meier) survival estimates indicated that, during a period of mortality, the risk of mortality varied appreciably among treatments. This is a situation in which proportional hazards modeling is suggested (Fox 1993). Based on the results of the proportional hazards analysis, we developed estimates of proportional survival over time for species $\times$ $\mathrm{N} \times$ light treatments using the Kaplan-Meier approach. We tested for significant differences in Kaplan-Meier estimates among treatment groups with log-rank and Wilcoxon tests (Kalbfleish and Prentice 1980). The log-rank test places more weight on larger survival times and is most useful when the ratio of hazard functions (hazard function $=$ instantaneous failure rate at a given time) in the groups being compared is approximately constant. The Wilcoxon test places more weight on early survival times and is the optimum rank test if the error distribution is logistic. From the Kaplan-Meier survival curve estimates we estimated four parameters. We estimated the proportion surviving at age $50 \mathrm{~d}$ and $100 \mathrm{~d}$ by interpolating between census dates on proportional survival vs. age curves to 50 and 100 d respectively. We estimated the day mortality began by extrapolating a best fit line to proportion surviving $=1.0$, where the line is based on the first three census dates following the commencement of a period of high and sustained mortality. Finally, we estimated mortality rate during the period of highest sustained risk, by determining the slope of the $\ln$ (proportion surviving) vs. age relationship from three or four census dates during the period of high mortality. Both the proportional hazards model for survival and ANOVA for plant mass and morphology generally indicated that species, light, $\mathrm{N}$, and their interactions were highly significant $(P<0.0001)$, and that these sources of variation explained more variation than did block and its interactions with species, light, and $\mathrm{N}$. Thus we reduced data to species $\times \mathrm{N} \times$ light $\times$ harvest means for presentation and subsequent analyses. Furthermore, the three $\mathrm{N}$ treatments were pooled for some analyses at very low light levels and the two lowest $\mathrm{N}$ treatments were pooled for most analyses at all light levels, since differences among these treatments were insignificant beyond the threshold suggested for pooling variances (i.e., $P>0.25$, Bancroft 1964). Thus, unless otherwise specified, the $3.4 \times 10^{-3} \mathrm{~mol} / \mathrm{L} \mathrm{N}$ treatment and the pooled $3.4 \times 10^{-6} \mathrm{~mol} / \mathrm{L} \mathrm{N}$ and $3.4 \times 10^{-9} \mathrm{~mol} / \mathrm{L} \mathrm{N}$ treatments are hereafter referred to as high and low $\mathrm{N}$ respectively. Following data reduction, we analyzed differences among treatments (Tukey-Kramer HSD) and relationships among growth, survival, and morphological characteristics (least squares linear regression, nonlinear regression, and Spearman's rank correlation) with JMP.

\section{RESULTS}

Survival: $N$ and light effects within species

Except for P. strobus, which had survival near $100 \%$ in all treatments, survival increased with light level
$(0.6 \%$ to $7.3 \%)$ for all species in all $\mathrm{N}$ treatments (Figs. 1 and $2, P<0.05$ for log-rank and Wilcoxon tests for all species $\times \mathrm{N}$ treatments). Increases in survival with light were greatest as light increased from $0.6 \%$ to $1.5 \%$ light, especially for conifer species. High $\mathrm{N}$ increased survival for small-seeded Betula spp. and P. tremuloides in all but the lowest light treatment $(0.6 \%)$, and the magnitude of this increase was greatest at the highest light level (7.3\%) (Fig. 1a, $P<0.001$ for each species, log-rank test). Compared to Betula spp. and P. tremuloides responses to $\mathrm{N}$ for the other species were much weaker and less consistent (Figs. $1 \mathrm{~b}$ and 2). High $\mathrm{N}$ increased survival only for P. mariana and L. laricina in $1.5 \%$ light and A. balsamea in $0.6 \%$ light, and high $\mathrm{N}$ decreased survival for $P$. banksiana in both $0.6 \%$ and $1.5 \%$ light and for B. papyrifera and $P$. resinosa in $0.6 \%$ light (Fig. 1a and b, $P<0.05$, log-rank test).

\section{Survival: differences across species}

In all $\mathrm{N}$ and light treatments, survival for broadleaved species generally followed the rank order: $A$. saccharum $>B$. alleghaniensis $>$ B. papyrifera $>P$. tremuloides. In $0.6 \%$ light, the only light treatment where a majority of conifer species showed $>20 \%$ mortality, survival rankings by the experiment's end were: P. strobus $>A$. balsamea $>$ P. mariana $>P$. resinosa $>$ L. laricina $>$ P. banksiana (Figs. 1 and 2). These rankings are similar to rankings of reported shade tolerance for these species (Table 1). At higher light levels, P. mariana and L. laricina generally had lower survival than other conifers. For these two species only, Fusarium infection (based on visual symptoms; C. Buschena, personal communication) caused $\sim 30 \%$ of total mortality, most of which occurred in the first $30 \mathrm{~d}$ of the experiment. For most other seedlings of all species, there was no obvious agent of mortality. Among broadleaved and conifer groups in both high and low $\mathrm{N}$ treatments, there was little evidence of rank reversals in survival between low and higher light levels. Compared to species with high survival in very low light, species that had low survival in very low light had similar (e.g., L. laricina) or lower (e.g., P. tremuloides) survival at slightly higher light levels (Fig. 2).

Survival vs. age relationships were generally characterized by an early period of low mortality (or mortality due to Fusarium) followed by an extended period of high mortality. The length of the low-mortality period varied among species (Fig. 1). For example, in $0.6 \%$ light ( $\mathrm{N}$ treatments combined) species differences were highly significant ( $P=0.0001$, Wilcoxon test) and ranged from $2 \mathrm{wk}$ for $P$. tremuloides, B. papyrifera, B. alleghaniensis, $P$. banksiana, and $P$. mariana to 75 $\mathrm{d}$ for $P$. resinosa. To a lesser extent than species differences, resource treatments, especially light, also affected the length of the early low-mortality period (Fig. 1). For example, for P. tremuloides, the low-mortality period was $10 \mathrm{~d}$ in $0.6 \%$ light and $22 \mathrm{~d}$ in $7.3 \%$ light. The maximum mortality rate during the period of high- 

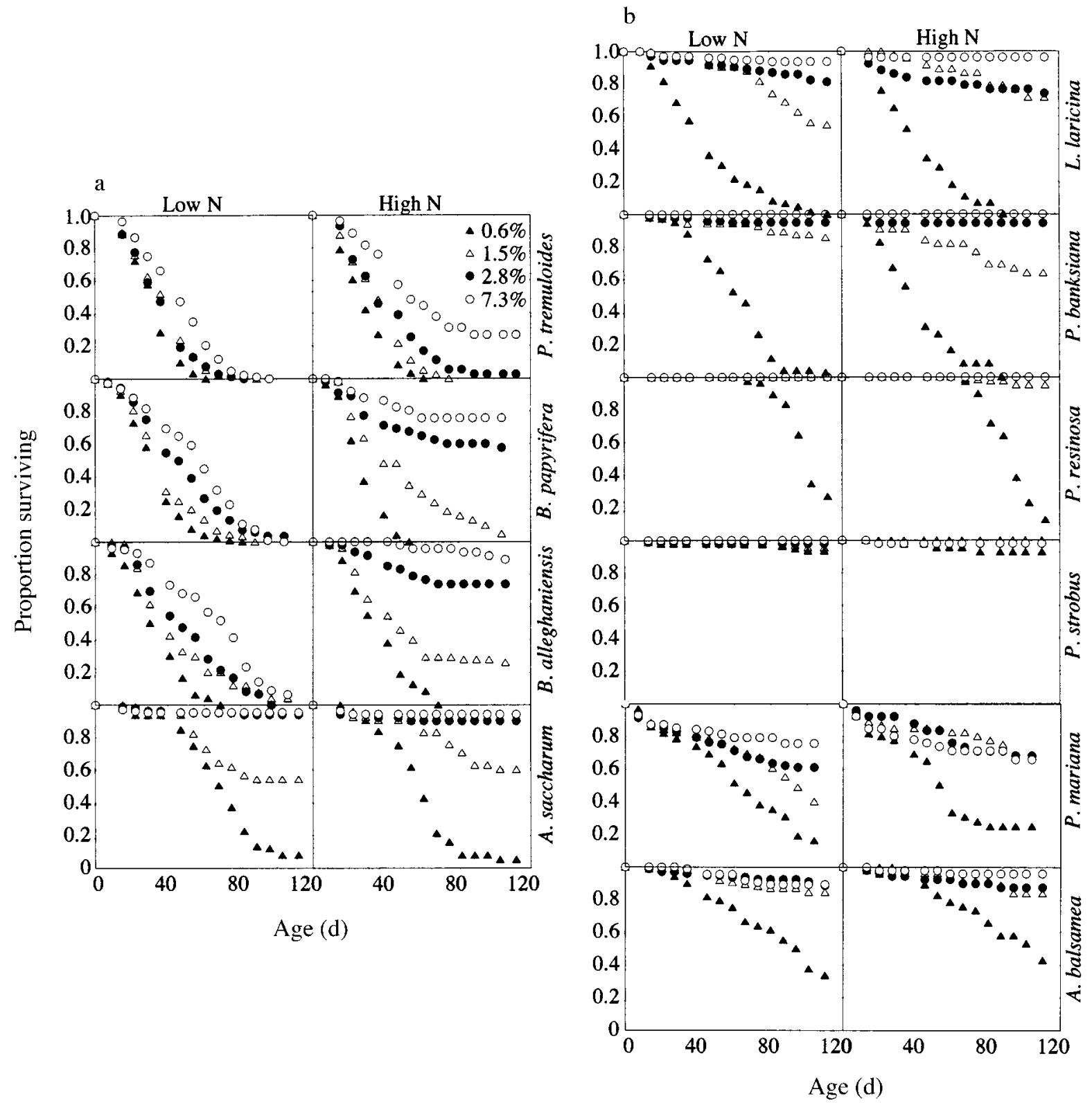

FIG. 1. The proportion of original seedling populations surviving vs. seedling age for each species $\times$ light treatment for high $\mathrm{N}\left(3.4 \times 10^{-3} \mathrm{~mol} / \mathrm{L} \mathrm{N}\right)$ and low $\mathrm{N}\left(3.4 \times 10^{-6} \mathrm{~mol} / \mathrm{L}\right.$ and $3.4 \times 10^{-9} \mathrm{~mol} / \mathrm{L}$ pooled $)$. Graphs are separated into (a) broad-leaved and (b) conifer species groups. Within each of these groups, species are presented top to bottom, from least to most shade tolerant (from Table 1).

mortality also varied among species (Fig. 1), and it was not correlated with the length of time before mortality occurred (e.g., for $0.6 \%$ light, Spearman's $\rho=0.38, P$ $=0.31$ ). For example, in $0.6 \%$ light, for species that had significant mortality, $P$. resinosa had twice as long a low-mortality period as any other species, but both $A$. balsamea and $P$. mariana had lower maximum mortality rates than $P$. resinosa (Fig. 1).

\section{Growth: $N$ and light effects within species}

As for survival there were strong interacting effects of light, N, and species on seedling mass (Fig. 3) and relative growth rate (RGR; Fig. 4). Seedling mass and RGR increased with light for all species in both high and low N, and RGR increases with light were greatest between the lowest light levels (Fig. 4). Nitrogen supply did not affect growth at the two lowest light levels, but at higher light, high $\mathrm{N}$ increased mass for all species, and these increases were greatest and generally occurred earlier for shade intolerant, small-seeded species. Furthermore, only for small-seeded, shade intolerant $P$. tremuloides, Betula spp., L. laricina, and $P$. banksiana did mass and RGR increase in $2.8 \%$ light 
FIG. 2. The proportion of the original seedling populations surviving in low $\left(3.4 \times 10^{-6}\right.$ $\mathrm{mol} / \mathrm{L}$ and $3.4 \times 10^{-9} \mathrm{~mol} / \mathrm{L}$ pooled) and high $\mathrm{N}\left(3.4 \times 10^{-3} \mathrm{~mol} / \mathrm{L} \mathrm{N}\right)$ treatments at 50 days of age for broad-leaved species and at 100 days of age for conifer species. Different ages are used for the two species groups because most conifers had little mortality by day 50 . Species abbreviations are: $P t=$ Populus tremuloides, $B p$ $=$ Betula papyrifera, $\mathrm{Ba}=$ Betula alleghaniensis, As $=$ Acer saccharum, $L l=$ Larix laricina, $P b=$ Pinus banksiana, $P r=$ Pinus resinosa, $P s$ = Pinus strobus, $P m=$ Picea mariana, $A b=$ Abies balsamea.

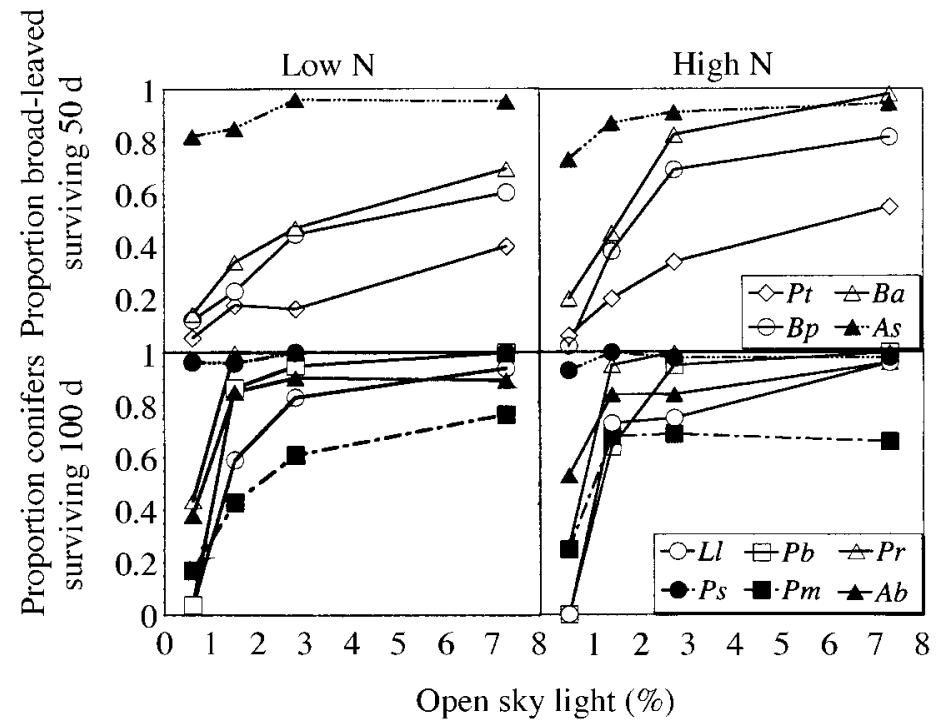

(Figs. 3 and 4). Even in the low $\mathrm{N}$ treatments, plants grew over time, with growth being greatest in $7.3 \%$ light (Figs. 3 and 4). However, there was very little increase in whole-plant $\mathrm{N}$ content in low $\mathrm{N}$ treatments and growth resulted in dilution of the seedling's initial $\mathrm{N}$ pool. For example whole-plant $\mathrm{N}$ concentration for $P$. resinosa in $7.3 \%$ light and low $\mathrm{N}$ was $11 \times$ higher for initial germinants $(8 \% \mathrm{~N})$ than seedlings at final harvest $(0.7 \% \mathrm{~N})$. This corresponded inversely to a $9 \times$ increase in mass from initial germinants $(5.8 \mathrm{mg})$ to third harvest seedlings $(52 \mathrm{mg})$. This indicates that young seedlings with high $\mathrm{N}$ concentrations can grow for a time in the absence of a $\mathrm{N}$ supply.

\section{Growth: differences across species}

In low light, RGR was low, and differences among species were generally small in both high and low $\mathrm{N}$ (Fig. 4). At higher light levels differences in RGR emerged between species, especially in high N. RGR in $2.7 \%$ and $7.3 \%$ light and high $\mathrm{N}$ were generally higher for small-seeded species and lowest for largeseeded species. There were few reversals in RGR rankings between very low and low light levels in the direction expected if maximizing RGR in very low light was an important corollary of shade tolerance. One of the few examples was shade-intolerant classified L. laricina, which had the lowest RGR of the conifers in $0.6 \%$ light and the second highest RGR in $7.3 \%$ light. However, overall, there was only weak evidence of growth rank reversals among species across light availabilities.

\section{Seedling morphology: $N$ and light effects within species}

At low light, there were no differences in LMR, RMR, and SLA between high and low N (Student's $t$, $P>0.05$ ) (Table 2). In contrast, at higher light, since growth rates were sufficient for the allocation of significant amounts of new mass to leaves and roots, species in high $\mathrm{N}$ generally allocated more to leaves and less to roots, with the opposite occurring in low $\mathrm{N}$. This resulted in higher LMR and lower RMR in 7.3\% light in high $\mathrm{N}$ than low $\mathrm{N}$ for most species $(P<0.05)$. In contrast to LMR and RMR, SLA was similar for high and low $\mathrm{N}$ in $7.3 \%$ light $(P>0.05)$.

\section{Seedling morphology: differences across species}

In all light and $\mathrm{N}$ levels, the most shade tolerant classified conifer, A. balsamea, had lower LMR, SLA, and LAR, and higher RMR than less-tolerant conifers. The same trend was found for the most tolerant broadleaved species, A. saccharum, compared to less tolerant broad-leaved species in high $\mathrm{N}$ treatments. However, in low $\mathrm{N}$, the distinction between $A$. saccharum and other broad-leaved species disappeared (Table 2 and data not shown).

\section{Relationships among survival, growth, and seedling mass}

Within species, survival was positively and continuously related to RGR regardless of the source of variation in RGR (light or N) (Fig. 5, $P<0.01$ for all nonlinear models). For any given RGR, shade-tolerant and large-seeded species had higher survival than intolerant and small-seeded species (Fig. 5).

In sharp contrast to strong positive relationships between survival and RGR within each species, across species, RGR and survival (at $50 \mathrm{~d}$ or $100 \mathrm{~d}$ ) were not correlated in any of the 12 unique light $\times \mathrm{N}$ treatments $(P>0.26$ in all cases). Unlike RGR, seed mass and survival at 50 days of age were strongly positively related across species in all 12 light $\times \mathrm{N}$ treatments $(P<0.006$ in all cases) and in 9 of 12 treatments (at $P<0.01)$ at 100 days of age. Seed mass increased 
b

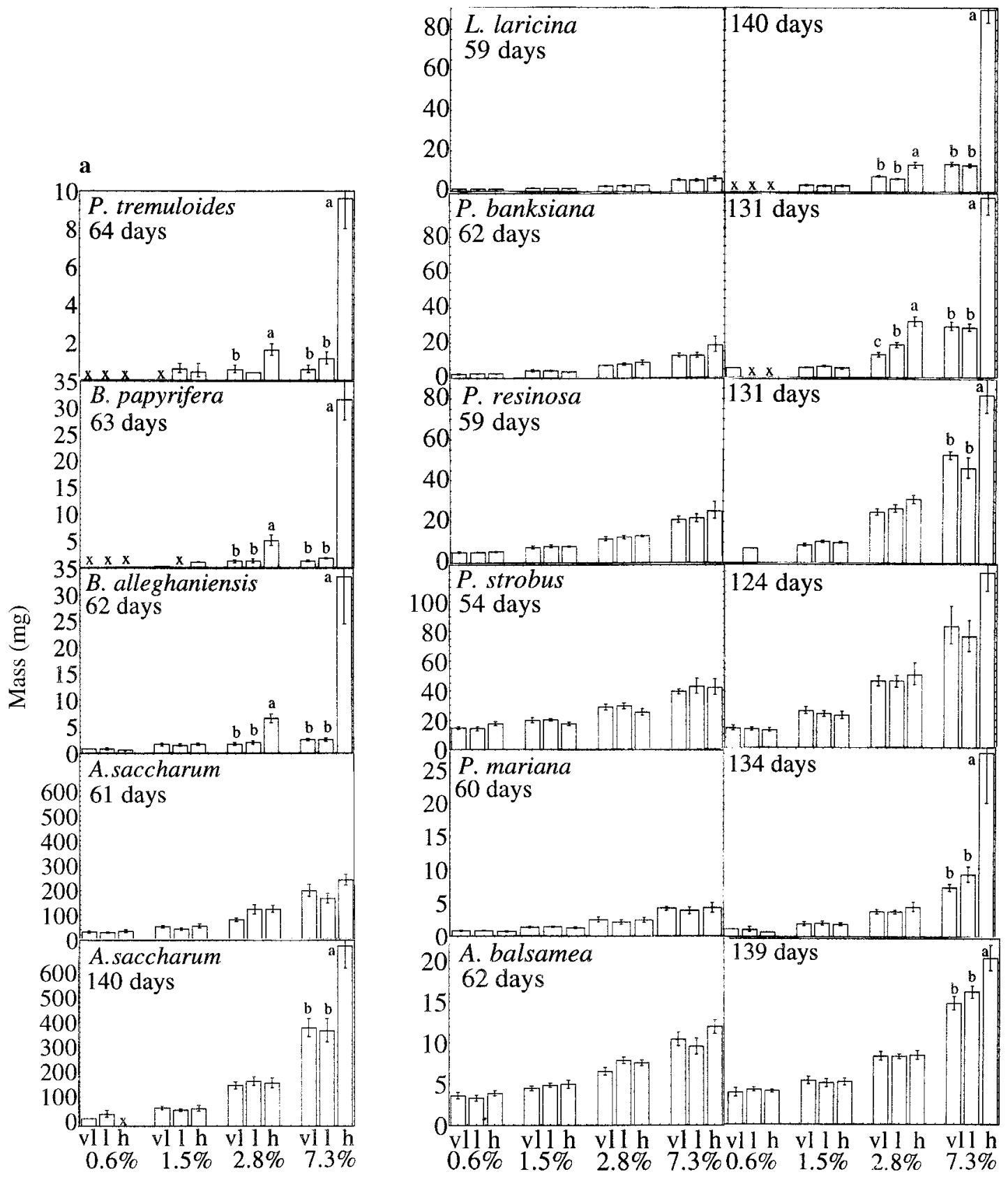

Nitrogen and light treatment

FIG. 3. Seedling mass at second and third harvests for each species $\times$ light $(0.6-7.3 \%) \times \mathrm{N}\left(\mathrm{vl}=3.4 \times 10^{-9} \mathrm{~mol} / \mathrm{L}, 1\right.$ $\left.=3.4 \times 10^{-6} \mathrm{~mol} / \mathrm{L}, \mathrm{h}=3.4 \times 10^{-3} \mathrm{~mol} / \mathrm{L}\right)$ treatment. Several third-harvest panels are not included since for these panels there were few treatments with live seedlings. Mean mass ( \pm SE) for treatments with live seedlings in excluded panels (all are from the high $\mathrm{N}$ treatment) are: for $P$. tremuloides, $186 \pm 40 \mathrm{mg}$ in $7.3 \%$ light; for B. papyrifera, $77 \pm 12 \mathrm{mg}$, and 678 $\pm 52 \mathrm{mg}$ in $2.8 \%$ and $7.3 \%$ light respectively; and for B. alleghaniensis, $4.1 \pm 1.1 \mathrm{mg}, 109 \pm 22 \mathrm{mg}$, and $610 \pm 42 \mathrm{mg}$ in $1.5 \%, 2.8 \%$, and $7.3 \%$ light, respectively. Different letters indicate significant differences among $\mathrm{N}$ treatments within species $\times$ light groups $(P<0.05$, Tukey-Kramer HSD). 
FIG. 4. Relative growth rates (RGR) between first and second harvests for broad-leaved and conifer species groups in high $\mathrm{N}(3.4 \times$ $\left.10^{-3} \mathrm{~mol} / \mathrm{L}\right)$ and low $\mathrm{N}\left(3.4 \times 10^{-6} \mathrm{~mol} / \mathrm{L}\right.$ and $3.4 \times 10^{-3} \mathrm{~mol} / \mathrm{L}$ pooled) (see Methods for rationale). Note differences in scale for broadleaved and conifer groups.

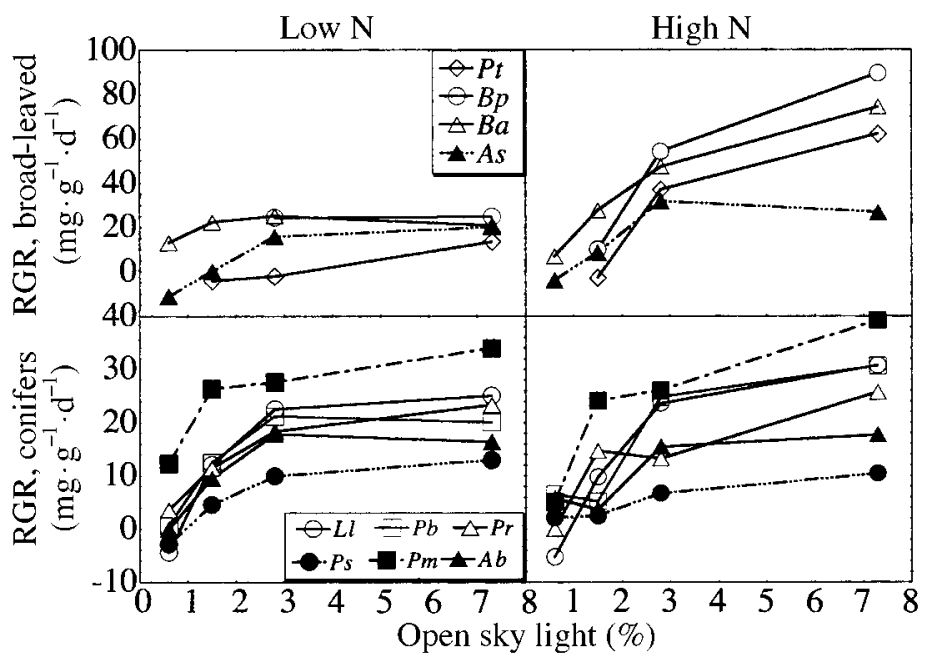

TABLE 2. Leaf mass ratio (LMR), root mass ratio (RMR), specific leaf area (SLA), and leaf area ratio (LAR) in $1.5 \%$ and $7.3 \%$ light, and high and low N.

\begin{tabular}{|c|c|c|c|c|c|c|c|c|}
\hline \multirow[b]{2}{*}{ Species } & \multicolumn{4}{|c|}{ Low $\mathrm{N}$} & \multicolumn{4}{|c|}{ High $N$} \\
\hline & LMR & RMR & SLA & LAR & LMR & RMR & SLA & LAR \\
\hline \multicolumn{9}{|l|}{ A) $1.5 \%$ light } \\
\hline P. tremuloides & $\ldots$ & ... & $\ldots$ & $\ldots$ & $\ldots$ & $\ldots$ & ... & ... \\
\hline B. papyrifera & $\cdots$ & $\cdots$ & $\cdots$ & $\cdots$ & $\begin{array}{c}0.60 \pm 0.04 \\
\mathrm{ab}\end{array}$ & $\begin{array}{c}0.23 \pm 0.02 \\
\mathrm{ab}\end{array}$ & $\begin{array}{c}920 \pm 173 \\
\mathrm{ab}\end{array}$ & $\begin{array}{c}548 \pm 91 \\
\mathrm{ab}\end{array}$ \\
\hline B. alleghaniensis & $\begin{array}{c}0.57 \pm 0.02 \\
\mathrm{abc}\end{array}$ & $\begin{array}{c}0.24 \pm 0.02 \\
\mathrm{abc}\end{array}$ & $\begin{array}{c}720 \pm 65 \\
a\end{array}$ & $\begin{array}{c}412 \pm 38 \\
\mathrm{a}\end{array}$ & $\begin{array}{c}0.63 \pm 0.01 \\
\mathrm{ab}\end{array}$ & $\begin{array}{c}0.22 \pm 0.01 \\
\mathrm{abc}\end{array}$ & $1040 \pm 91 \mathrm{a}$ & $\begin{array}{c}655 \\
\mathrm{a}\end{array}$ \\
\hline A. saccharum & $\begin{array}{c}0.44 \pm \frac{ \pm}{c} \\
0.03\end{array}$ & $\begin{array}{c}0.25 \pm 0.03 \\
\mathrm{ab}\end{array}$ & $\begin{array}{c}621 \pm 30 \\
\mathrm{ab}\end{array}$ & $284 \pm 0.28$ & $0.42 \pm \frac{0.03}{c}$ & $\begin{array}{c}0.25 \pm 0.04 \\
\mathrm{a}\end{array}$ & $\begin{array}{c}546 \pm 54 \\
\mathrm{bc}\end{array}$ & $\begin{array}{c}303 \pm 13 \\
\mathrm{c}\end{array}$ \\
\hline L. laricina & $\begin{array}{c}0.63 \pm 0.04 \\
\mathrm{ab}\end{array}$ & $0.14 \underset{\mathrm{cd}}{ \pm 0} 0.03$ & $429 \underset{b c}{ \pm} 81$ & $261 \frac{ \pm}{\mathrm{b}} 0.40$ & $0.65 \pm 0.01$ & $0.11 \underset{\mathrm{cd}}{ \pm 0.02}$ & $\begin{array}{c}497 \pm 93 \\
\text { bcd }\end{array}$ & $\begin{array}{c}322 \pm 53 \\
\mathrm{bc}\end{array}$ \\
\hline P. banksiana & $\begin{array}{c}0.68 \pm 0.01 \\
\mathrm{a}\end{array}$ & $0.10 \pm 0.01$ & 477 & 324 & $\begin{array}{c}0.68 \pm 0.03 \\
\mathrm{a}\end{array}$ & $0.13 \pm 0.01$ & 406 & 276 \\
\hline P. resinosa & $\begin{array}{c}0.57 \pm 0.03 \\
\mathrm{abc}\end{array}$ & $\begin{array}{c}0.16 \pm 0.01 \\
\text { bcd }\end{array}$ & $289 \pm 10 \mathrm{~cd}$ & $164 \underset{\mathrm{bc}}{ \pm 0.10}$ & $\begin{array}{c}0.62 \pm 0.01 \\
\mathrm{ab}\end{array}$ & $\begin{array}{c}0.14 \pm 0.01 \\
\text { bcd }\end{array}$ & $\begin{array}{c}326 \pm 9 \\
\mathrm{~cd}\end{array}$ & $\begin{array}{c}203 \pm 4 \\
\mathrm{~cd}\end{array}$ \\
\hline P. strobus & $\begin{array}{c}0.57 \pm 0.03 \\
\mathrm{abc}\end{array}$ & $\begin{array}{c}0.17 \pm 0.02 \\
\text { bcd }\end{array}$ & 262 & 149 & $0.60 \pm 0.02$ & $0.14 \pm 0.02$ & 259 & 155 \\
\hline P. mariana & $\begin{array}{c}0.59 \pm 0.04 \\
\text { abc }\end{array}$ & $\begin{array}{c}0.17 \pm 0.03 \\
\mathrm{bc}\end{array}$ & $\begin{array}{c}474 \pm 43 \\
\mathrm{bc}\end{array}$ & $\begin{array}{c}280 \pm 0.46 \\
\mathrm{ab}\end{array}$ & $\begin{array}{c}0.70 \pm 0.02 \\
\mathrm{a}\end{array}$ & $0.11 \pm 0.01$ & $\begin{array}{c}441 \pm 42 \\
\text { cd }\end{array}$ & $\begin{array}{c}308 \pm 22 \\
\mathrm{c}\end{array}$ \\
\hline A. balsamea & $\begin{array}{c}0.52 \pm 0.05 \\
\mathrm{bc}\end{array}$ & $\begin{array}{c}0.27 \pm 0.02 \\
\mathrm{a}\end{array}$ & $186 \pm \frac{\mathrm{d}}{\mathrm{d}} 16$ & $\begin{array}{c}97 \pm 0.10 \\
\mathrm{c}\end{array}$ & $\begin{array}{c}0.58 \pm 0.04 \\
\mathrm{ab}\end{array}$ & $\begin{array}{c}0.16 \pm 0.02 \\
\text { abcd }\end{array}$ & $149 \pm 0.21$ & $85 \pm 6$ \\
\hline \multicolumn{9}{|l|}{ B) $7.3 \%$ light } \\
\hline P. tremuloides & $0.35 \pm 0.11$ & $\begin{array}{c}0.36 \pm 0.09 \\
\text { abcd }\end{array}$ & $\begin{array}{c}677 \pm 203 \\
\mathrm{ab}\end{array}$ & $\begin{array}{c}192 \pm 37 \\
\mathrm{ab}\end{array}$ & $\begin{array}{c}0.66 \pm 0.03 \\
\mathrm{ab}\end{array}$ & $\begin{array}{c}0.15 \pm 0.02 \\
\mathrm{~b}\end{array}$ & $\begin{array}{c}645 \pm 114 \\
\mathrm{a}\end{array}$ & $\begin{array}{c}431 \pm 70 \\
\mathrm{ab}\end{array}$ \\
\hline B. papyrifera & $0.39 \pm 0.05$ & $\begin{array}{c}0.40 \pm 0.05 \\
\mathrm{a}\end{array}$ & $\begin{array}{c}524 \pm 76 \\
\mathrm{ab}\end{array}$ & $\begin{array}{c}196 \pm 39 \\
\mathrm{ab}\end{array}$ & $\begin{array}{c}0.69 \pm 0.01 \\
\mathrm{ab}\end{array}$ & $0.15 \pm 0.01$ & $\begin{array}{c}493 \pm 99 \\
\mathrm{ab}\end{array}$ & $\begin{array}{c}340 \pm 71 \\
\text { abc }\end{array}$ \\
\hline A. saccharum & $0.40 \pm 0.02$ & $\begin{array}{c}0.42 \pm 0.03 \\
\mathrm{a}\end{array}$ & $\begin{array}{c}421 \pm 60 \\
\mathrm{bc}\end{array}$ & $170 \pm \frac{8}{b}$ & $0.47 \pm \frac{0.07}{\mathrm{c}}$ & $\begin{array}{c}0.36 \pm 0.06 \\
\mathrm{a}\end{array}$ & $\begin{array}{c}450 \pm 68 \\
\mathrm{ab}\end{array}$ & $\begin{array}{c}238 \pm 98 \\
\text { bcd }\end{array}$ \\
\hline L. laricina & $\begin{array}{c}0.66 \pm 0.02 \\
\mathrm{a}\end{array}$ & $\begin{array}{c}0.18 \pm 0.03 \\
\mathrm{e}\end{array}$ & $\begin{array}{c}241 \pm 13 \\
\mathrm{~cd}\end{array}$ & $\begin{array}{c}159 \pm 7 \\
\mathrm{bc}\end{array}$ & $\begin{array}{c}0.77 \pm 0.03 \\
\mathrm{a}\end{array}$ & $0.14 \frac{ \pm}{b} 0.02$ & $336 \pm 10$ & $\begin{array}{c}259 \pm 8 \\
\text { bcd }\end{array}$ \\
\hline P. banksiana & $\begin{array}{c}0.63 \pm 0.01 \\
\mathrm{a}\end{array}$ & $\begin{array}{c}0.22 \pm 0.02 \\
\text { cde }\end{array}$ & $\begin{array}{c}209 \pm 4 \\
\mathrm{~cd}\end{array}$ & $\begin{array}{c}132 \pm 5 \\
\mathrm{bc}\end{array}$ & $\begin{array}{c}0.73 \pm 0.02 \\
\mathrm{ab}\end{array}$ & $0.13 \pm 0.01$ & $299 \pm \frac{19}{b}$ & $\begin{array}{c}221 \pm 20 \\
\text { bcd }\end{array}$ \\
\hline P. resinosa & $\begin{array}{c}0.65 \pm 0.01 \\
\mathrm{a}\end{array}$ & $0.20 \pm 0.02$ & $\begin{array}{c}198 \pm 11 \\
\mathrm{~cd}\end{array}$ & $\begin{array}{c}128 \pm 6 \\
\mathrm{bc}\end{array}$ & $\begin{array}{c}0.71 \pm 0.05 \\
\mathrm{ab}\end{array}$ & $0.17 \underset{\mathrm{b}}{ \pm} 0.05$ & $241 \pm 46$ & $\begin{array}{c}166 \pm 20 \\
\mathrm{~cd}\end{array}$ \\
\hline P. strobus & $\begin{array}{c}0.56 \pm 0.04 \\
\mathrm{abc}\end{array}$ & $\begin{array}{l}0.25 \pm 0.01 \\
\text { bcde }\end{array}$ & $188 \pm 6$ & $117 \pm 17$ & $\begin{array}{c}0.64 \pm 0.02 \\
\mathrm{abc}\end{array}$ & $0.14 \underset{\mathrm{b}}{ \pm} 0.01$ & $198 \pm \frac{ \pm}{b}$ & $124 \frac{ \pm}{\mathrm{d}} 4$ \\
\hline P. mariana & $\begin{array}{c}0.58 \pm 0.01 \\
\mathrm{ab}\end{array}$ & $\begin{array}{l}0.26 \pm 0.01 \\
\text { bcde }\end{array}$ & $\begin{array}{c}295 \pm 13 \\
\mathrm{~cd}\end{array}$ & $172 \pm \frac{9}{b}$ & $\begin{array}{c}0.70 \pm 0.04 \\
\mathrm{ab}\end{array}$ & $0.13 \pm 0.03$ & $\begin{array}{c}454 \pm 25 \\
\mathrm{ab}\end{array}$ & $\begin{array}{c}321 \pm 33 \\
\text { abc }\end{array}$ \\
\hline A. balsamea & $\begin{array}{c}0.44 \pm 0.01 \\
\text { bcd }\end{array}$ & $\begin{array}{c}0.36 \pm 0.02 \\
\mathrm{abc}\end{array}$ & $142 \pm \frac{\mathrm{d}}{\mathrm{d}} 6$ & $\begin{array}{c}61 \pm 4 \\
\mathrm{c}\end{array}$ & $\begin{array}{c}0.57 \pm 0.03 \\
\mathrm{bc}\end{array}$ & $\begin{array}{c}0.27 \pm 0.03 \\
\mathrm{ab}\end{array}$ & $133 \pm \frac{ \pm}{b}$ & $72 \pm 6$ \\
\hline
\end{tabular}

Notes: Data are means $( \pm 1 \mathrm{SE})$ for plants from the second harvest except SLA and LAR for $P$. strobus and $P$. banksiana, which are the means of harvests 1 and 3. For each light level, species without common letters within a column are significantly different $(P<0.05$, Tukey-Kramer HSD). 

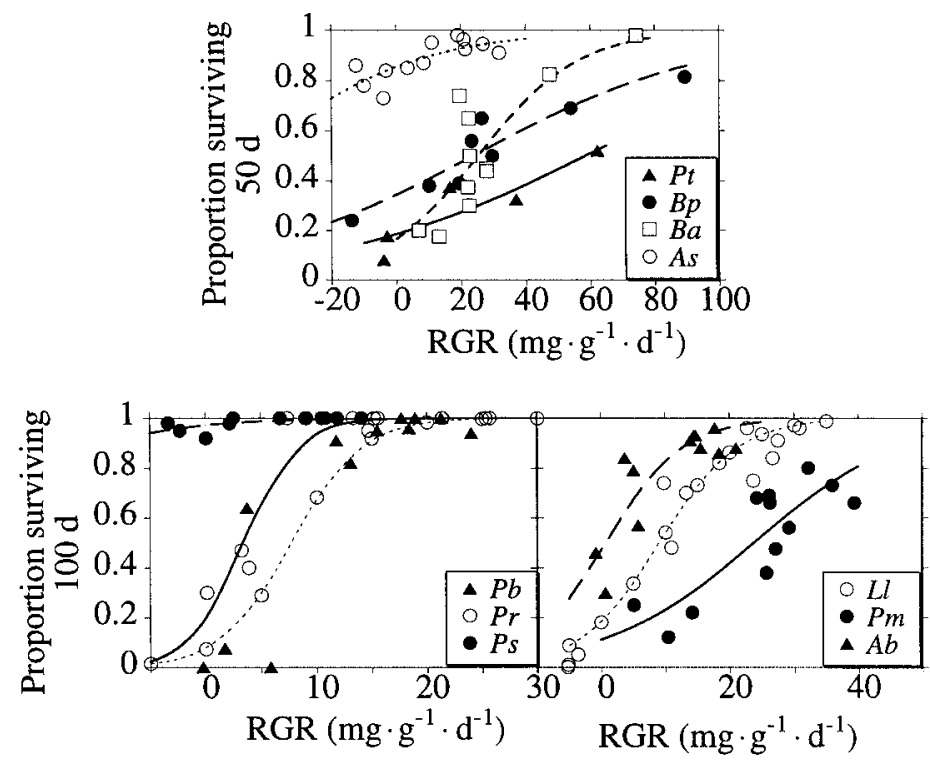

FIG. 5. Relationships of proportional survival vs. relative growth rate (RGR; between the first and second harvests) for each species. Proportional survival is the proportion of the original seedling population alive 50 days following germination for the broad-leaved group, and 100 days following germination for the conifer groups. Each datum is a species $\times$ light $\times \mathrm{N}$ treatment average. For clarity of presentation, data for each species were fitted with logistic functions of the general form: $\theta_{1} /(1+$ $\left.\theta_{2} \cdot \exp \left(\theta_{3} \cdot \mathrm{RGR}\right)\right)$. We solved for the best fit logistic function (i.e., residual sums of squares error minimized) by setting $\theta_{1}$ to 1 and solving for $\theta_{2}$ and $\theta_{3}$ iteratively using the nonlinear fit platform of JMP (SAS Institute, Cary, North Carolina, USA). All fits are significant at $P<$ 0.05. Species abbreviations are as in Fig. 2 legend. survival both by increasing the length of the period before mortality began and by decreasing the daily mortality rate during the period of high-mortality (Table 3). Collectively these patterns resulted in a strong three-way interrelationship between seed mass, RGR, and survival across $\mathrm{N}$ and light treatments (Fig. 6). At any given RGR, large seeded species always had higher survival than smaller-seeded, intolerant ones. Thus, in low light and/or $\mathrm{N}$ environments where RGR is low and similar for all species, survival increases strongly with seed mass. However, as RGR and survival increase with light and $\mathrm{N}$ availabilities, differences in survival among small and large-seeded species diminish.

Like seed size, shade tolerance rank (Table 1) correlated with survival in shade but not with RGR. However, compared to seed mass, shade tolerance rank correlated more strongly with maximum mortality rate and less strongly with the age that mortality began (Table
3). Tolerance ranking and seed mass differed in the strength of their correlation with survival (Table 3), in part, because seed mass and shade tolerance rank were only weakly correlated $(\rho=0.61, P=0.055$. Thus, traits associated with tolerance other than seed size promote low-mortality rates for tolerant seedlings once the effects of large-seededness on delaying the onset of mortality have disappeared.

Although interspecific variation in survival in low light $(0.6 \%$ and $1.5 \%)$ was unrelated to RGR in the same low light treatment (Table 3), low-light survival was negatively related to RGR measured in higher light $(7.3 \%)$ and high $\mathrm{N}$ (e.g., $0.6 \%$ light at $50 \mathrm{~d}, \rho=-0.91$, $P=0.0002)$. Therefore, species with high growth rates in higher resource environments had higher mortality rates in low-resource environments. This relationship is at least partially related to seed mass, since seed mass was positively related to survival in low light

TABLE 3. Summary of Spearman's nonparametric correlations (Spearman's $\rho[P<|\rho|])$ of survival characteristics with seed mass, RGR, and shade tolerance rank in $0.6 \%$ and $1.5 \%$ light.

\begin{tabular}{|c|c|c|c|c|c|}
\hline Light level & Parameter & $\begin{array}{c}\text { Proportion } \\
\text { surviving } \\
50 \mathrm{~d}\end{array}$ & $\begin{array}{c}\text { Proportion } \\
\text { surviving } \\
100 \mathrm{~d}\end{array}$ & $\begin{array}{c}\text { Maximum } \\
\text { mortality rate }\end{array}$ & $\begin{array}{c}\text { Age mortality } \\
\text { begins }\end{array}$ \\
\hline \multirow[t]{3}{*}{$0.6 \%$ light } & seed mass & $0.86 * *$ & $0.79 * *$ & -0.64 & $0.69 *$ \\
\hline & $\begin{array}{l}\text { RGR } \\
\text { shade }\end{array}$ & -0.45 & -0.26 & +0.04 & -0.40 \\
\hline & tolerance rank & -0.61 & $-0.65^{*}$ & $+0.84 * *$ & -0.45 \\
\hline \multirow[t]{3}{*}{$1.5 \%$ light } & seed mass & $0.79 * *$ & $0.81^{* *}$ & $\ldots$ & $\ldots$ \\
\hline & $\begin{array}{l}\text { RGR } \\
\text { shade }\end{array}$ & 0.41 & 0.39 & $\ldots$ & $\ldots$ \\
\hline & tolerance rank & -0.32 & -0.35 & $\ldots$ & $\ldots$ \\
\hline
\end{tabular}

Notes: $\mathrm{N}$ treatments were pooled within light levels. Significant correlations are indicated as: $* P<0.05 ; * * P<0.01$. Maximum mortality rate and the age when mortality begins were not determined for $1.5 \%$ light, since low mortality for several species made it difficult to estimate parameters with high precision. For correlations with maximum mortality rate and age when mortality begins, $n=9$; for all correlations in $1.5 \%$ light and for proportion surviving correlations in $1.6 \%$ light, $n=10$; for others, $n=8$. 

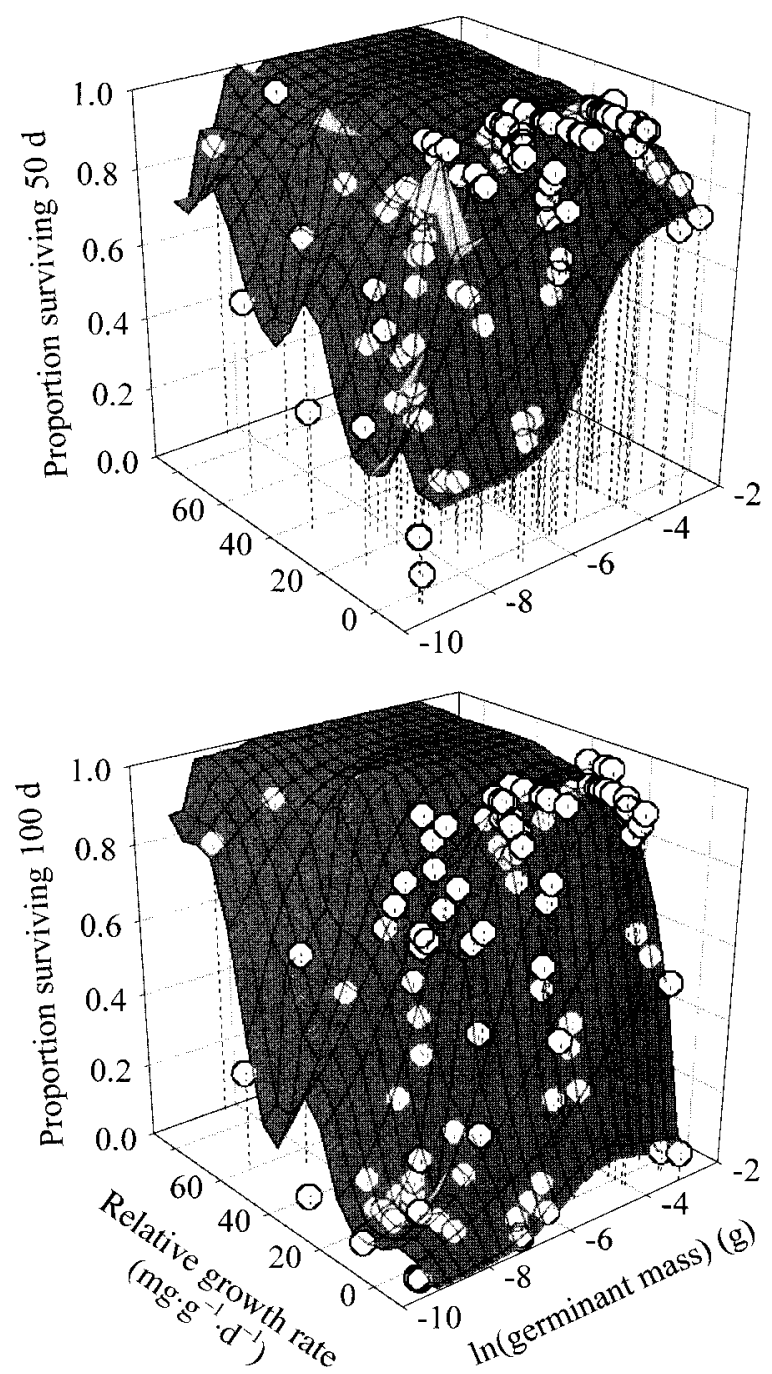

FIG. 6. Three-way relationship among the natural logarithm of seed mass, relative growth rate, (RGR; between first and second harvests), and proportional survival at 50 and 100 days seedling age. Each datum is a species $\times$ light $\times \mathrm{N}$ treatment average except for seed mass, which is a species average. The mesh was interpolated (SigmaPlot, Jandel Scientific, San Rafael, California, USA) from predicted values from nonlinear logistic regressions between RGR and survival for each species (see Fig. 5). The weighting used for the interpolation was chosen subjectively.

(Table 3) and negatively related to RGR only in $2.8 \%$ and $7.3 \%$ light and high $\mathrm{N}$ (e.g., 7.3\% light, $\rho=-0.88$, $P=0.0008)$. As for seed mass, LAR was strongly $(P$ $<0.01)$ related to RGR across species in the high $\mathrm{N}$ treatment in 7.3 and $2.8 \%$ light, but the strength and the slope of the relationship decreased with light level (Fig. 7a). LAR relationships with RGR were weak at all light levels in low N (Fig. 7b).

\section{Discussion}

Our results demonstrate that first-year seedling survival in shade is a function of seed size, growth rate
(RGR), and unidentified physiological factors related to species shade tolerance ranking. Variation in RGR, as driven by variation in light and $\mathrm{N}$, was strongly related to survival within species. In contrast, across species, differences in seed mass and not RGR correlated with early seedling survival. Our results also suggest that the positive effects of seed size on survival are temporary. Once species began incurring high mortality rates in very low light (i.e., $\sim 14-75 \mathrm{~d}$ after germination for all species but $P$. strobus), mortality rates were more closely related to shade tolerance rankings than seed size.

\section{Characteristics of shade tolerant species in low light}

Shade tolerance is, by our definition, the ability to survive in deep shade. However, the relative ability of tree species to maintain populations of vigorous seedlings and saplings in forest understories is the likely basis of observational shade tolerance classifications, and many factors in addition to young seedling survival could underlie these patterns. However, the positive correlations we found of observationally based shade tolerance ranks with proportional survival and maximum mortality rate strongly suggests that first-year survival is a key trait contributing to species abilities to maintain populations of vigorous juveniles in forest understories. Our data also suggest that seed size is an important corollary of low-light survival for very young seedlings. However, the stronger correlation of maximum mortality rate with shade tolerance rank than with seed size suggests that other, physiological factors may underlie longer-term survival in low light. By any measure, survival for $P$. resinosa and $P$. strobus was greater than expected based on our shade tolerance rankings, perhaps because they had the largest seeds of any of the conifers. Despite these anomalies, general agreement between survival and shade tolerance rankings suggests that characteristics governing survival in first-year seedlings contribute significantly to the overall suite of traits that confer shade tolerance.

Compared to less tolerant species, the most shadetolerant species generally had similar low-light RGR, lower LAR and LMR, and higher RMR. Thus, intolerant species had greater growth potential than tolerant species in low light, but low light prevents the full expression of these differences. Thus our results are inconsistent with the popular notion that shade tolerance is characterized by enhanced growth potential in low light (e.g., Loach 1967, 1970, Björkman 1981, Walters and Field 1987, Givnish 1988, Walters and Reich 1996). Our results are more consistent with the notion that shade tolerance is associated with biomass and energy conservation traits that maximize survival, but which can only occur at a tradeoff with traits that enhance growth potential (e.g., Coley 1988, Walters et al. 1993b, Kitajima 1994, Kobe 1997). High LAR may be an example of a trait that is advantageous in high light environments, but which may be disadvantageous 


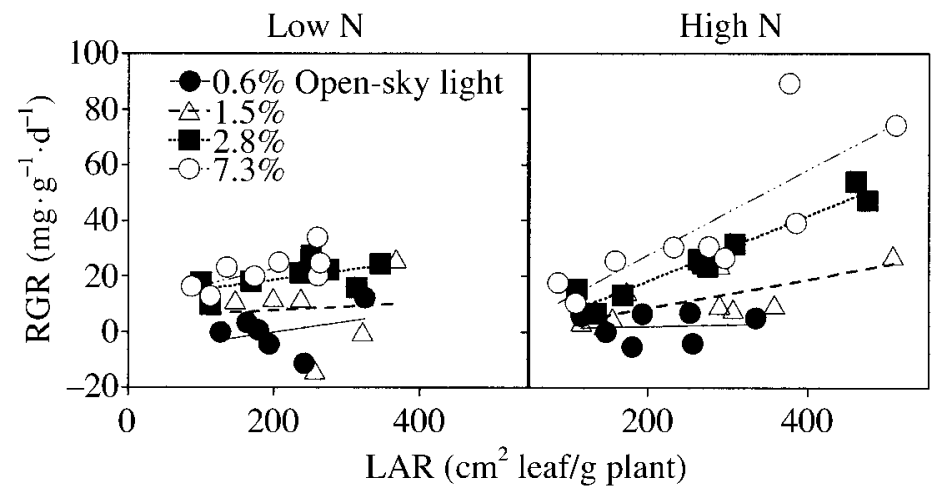

in very low light. LAR is a well established determinant of RGR in moderately low to high light (reviewed by Lambers and Poorter 1992, Reich et al. 1992, Cornelissen et al. 1996, and Poorter and Van Der Werf 1998). The adaptive importance of high LAR for intolerant/ pioneer species is also well established, since these species generally have higher LAR and growth rates, thus they are able to preempt growing space from slower growing neighbors. However, for a given increase in LAR, the incremental increase in RGR is much less in deep shade than in moderate light (Reich et al. 1998) or high light (Walters et al. 1993a, $b$ ). In addition, there may be costs to maximizing LAR, such as higher probabilities of damage for high SLA leaves (Coley 1988), less carbohydrate allocation to storage (Kobe 1997), higher whole-plant respiration rates (Walters and Reich 2000), or greater leaf turnover rates (Walters and Reich 1999). Thus, as the incremental increase in growth rate for a given increase in LAR diminishes with decreasing light level, the incremental costs/risks associated with that increase in LAR may become more important to growth and survival.

In an earlier outdoor experiment (Walters and Reich 1996), we found greater growth rates for shade-tolerant than intolerant species in low light ( $2 \%$ open sky) and positive growth vs. survival relationships across species. These findings contrast with this study's results and those of Kitajima (1994), both of which were greenhouse studies of young seedlings. These discrepancies among experiments may potentially be reconciled by differences in growing conditions and age. Seedlings in our outdoor experiment (Walters and Reich 1996) often faced suboptimal growing season conditions, dormancy over winter, seasonal tissue turnover, and herbivory from slugs. These conditions may have resulted in greater growth for shade-tolerant than intolerant species even if they had similar physiological growth potentials, if shade-tolerant species were more effective at minimizing tissue loss, since: realized growth $=$ growth potential - tissue losses (Kitajima
FIG. 7. Relative growth rate (RGR; between first and second harvest) vs. leaf area ratio (LAR; average of first and second harvest) for low $\mathrm{N}\left(3.4 \times 10^{-6} \mathrm{~mol} / \mathrm{L}\right.$ and $3.4 \times 10^{-9} \mathrm{~mol} /$ $\mathrm{L}$ pooled $)$ and high $\mathrm{N}\left(3.4 \times 10^{-3} \mathrm{~mol} / \mathrm{L}\right)$ seedlings in each light treatment. Each data point is a species average. Summary statistics for least squares linear regressions, including equations for significant $(P<0.10)$ regressions, are: for high $\mathrm{N}, \quad 7.3 \%$ light, $\mathrm{RGR}=-2.9+$ 0.150 (LAR), $R^{2}=0.66, P=0.008, n=9 ; 2.8 \%$ light, $\mathrm{RGR}=-4.8+0.120(\mathrm{LAR}), R^{2}=0.93$, $P<0.0001, n=9 ; 1.5 \%$ light, $\mathrm{RGR}=-0.2$ $+0.050(\mathrm{LAR}), R^{2}=0.49, P=0.054, n=8$; $0.6 \%$ light, $R^{2}=0.02, P=0.772, n=6$; for low N, 7.3\% light, RGR $=10.48+0.062$ (LAR), $R^{2}=0.66, P=0.06, n=8 ; 2.8 \%$ light, $R^{2}=$ $0.34, P=0.13, n=8 ; 1.5 \%$ light, $R^{2}=0.01$, $P=0.834, n=7 ; 0.6 \%$ light, $R^{2}=0.12, P=$ $0.497, n=6$.
1996). Furthermore, seedlings in Walters and Reich (1996) were grown for two years, compared to 140 days in this experiment. Thus, they may have been well beyond the effects of seed size on survival.

Interpreting our RGR-survival relationships among species does require one caveat. If seedlings with highest RGR within a treatment were the ones most likely to survive, then RGR would be overestimated for treatments with high mortality rates. Thus, the lack of a positive RGR-survival relationship among species could in part be artifactual. We explored this possibility by analyzing the relationship between RGR (between the first and second harvest) and proportional survival (at $100 \mathrm{~d}$ ) among species light and nitrogen treatments containing the greatest number of species with little mortality before the second harvest (when RGR is determined). In $1.5 \%$ light, all species except $P$. tremuloides, B. papyrifera, and B. alleghaniensis, had $<20 \%$ mortality by the second harvest. Excluding these three species, we still found no relationship between RGR and survival across species both in each $\mathrm{N}$ treatment and for $\mathrm{N}$ treatments pooled $(P>0.25$ in all cases, data not shown).

\section{Light and $N$ effects on growth and survival within species}

In contrast to the poor RGR-survival relationship among species in low light, within species, survival was positively related to RGR and both RGR and survival increased with increasing light and $\mathrm{N}$ availability. Furthermore, except in very low light, species generally responded to increased $\mathrm{N}$ by increasing growth and allocation to leaves, and in the smallest seeded, shadeintolerant species, by increasing survival. Therefore, factors in forest understories that increase growth, such as slightly higher light microsites or greater belowground resource availability, may increase survival, and at least in the short term, survival is increased the most for the species with smallest seeds that are the least tolerant. 
How increased RGR decreases mortality rate is unknown. RGR could be positively autocorrelated with other factors that increase the vigor of seedlings, such as carbohydrate storage concentrations or protective structure and chemistry. Alternatively, greater RGR could result in a faster escape from size dependent mortality. Our data, while not collected to examine these hypotheses, suggests that both mechanisms are important. Indications that higher RGR increases the physiological robustness of seedlings included: 1) the general pattern of increasing mortality rate with age, which would be expected if increasing carbon starvation over time in low light increases a seedling's risk of mortality; and 2) mortality from Fusarium in L. laricina and $P$. mariana was highest in the lowest light treatments, suggesting that plants with severe carbon shortages are more susceptible to pathogens, as has been reported by others (e.g., Augspurger 1984). The importance of high RGR for escaping size-dependent mortality is suggested by the growth and survival patterns of the three species-resource treatments that had both the highest RGR and the smallest seed mass, i.e., $P$. tremuloides, B. papyrifera, and B. alleghaniensis in high $\mathrm{N}$ and the two highest light treatments. Only in these six species-treatment combinations, where mass increased more than in any other treatments, did instantaneous per capita mortality rates also decrease dramatically over the course of the experiment (Fig. 1). Although RGR was highest in these treatments, it decreased as seedlings aged, while mortality rates also decreased. This suggests that, for these treatments, at any point in time, size was more important than RGR in determining changes in per capita mortality rates. For example, between 18 and $63 \mathrm{~d}$ and between 64 and $132 \mathrm{~d}$ for $B$. papyrifera in $2.8 \%$ light and high N, RGR was 54 and $34 \mathrm{mg} \mathrm{g}^{-1} \cdot \mathrm{d}^{-1}$, average daily mortality rate was 0.0068 and 0.0017 , and average mass was 2.7 and $33 \mathrm{mg}$ respectively.

Increases in growth rate with light were greatest at lower light levels (Fig. 4), a response which may be explained by two factors. First, the very young seedlings used in this experiment had simple monolayer leaf canopies of shade acclimated foliage, so their canopies may have been close to light saturation for photosynthesis at relatively low irradiances. Second, in low $\mathrm{N}$ treatments RGR may have been $\mathrm{N}$ limited, with the magnitude of this limitation increasing with light level. Low N nutrition decreased RGR most for species with high RGR in high $\mathrm{N}$, i.e., the three least tolerant and smallest-seeded broad-leaved species, P. tremuloides, B. papyrifera, and B. alleghaniensis.

High $\mathrm{N}$ availability increased growth in $7.3 \%$ light for all species and in $2.8 \%$ light only for the five most shade-intolerant species: $P$. tremuloides, B. papyrifera, B. alleghaniensis, L. laricina, and P. banksiana. The pattern in $2.8 \%$ light may arise from differences in RGR and initial germinant $\mathrm{N}$ content among species. All species grew in $2.8 \%$ and $7.3 \%$ light. However, species that had some combination of high RGR and small seed mass exhausted their initial $\mathrm{N}$ contents and thus became potentially $\mathrm{N}$ limited faster and at greater risk of mortality than large-seeded, low RGR species (Grubb and Burslem 1998). Compared to early successional habitats, nutrient availability for young seedlings growing in forest understories may be low in general (Vitousek et al. 1989; M. B. Walters, unpublished data) and highly unpredictable spatially (Jackson and Caldwell 1993). Therefore, high initial N contents and a low RGR may aid young seedlings in establishing a size sufficient to enhance the probability of nutrient capture and provide them with an extended period before their nutrient pools are diluted to critically low concentrations (Milberg et al. 1998).

\section{Summary}

Our results demonstrate that, within species, survival in shade is strongly related to RGR and that both increased light and $\mathrm{N}$ can increase RGR, especially for shade-intolerant species. Conversely, among species, seed size was related to young seedling survival, but RGR was not. In general, compared to intolerant species, species classified as tolerant had larger seeds, lower or similar allocation to leaves, and in very low light, similar RGR and higher survival. Our data also indicate that maximum mortality rates, an index of longer-term survival, were more closely related to shade tolerance classifications than seed size. This suggests that the positive effects of seed size on survival are temporary and that young seedlings of shade-tolerant species have physiological traits unrelated to RGR that enhance survival. Identifying and quantifying the relative importance of these physiological traits will likely require the explicit consideration of tradeoffs between growthrelated traits and traits promoting protection, maintenance, and storage (Coley 1988, Chapin et al. 1990, Walters 1993b, Kitajima 1994, Kobe 1997).

\section{ACKNOWLEDGMENTS}

We are grateful for the contributions of several people to this work at various stages. Tim Baker aided in the experiment's design, establishment, data collection, and maintenance. Todd Maveus, Susan Christensen, and John Gerlach provided expert technical support. The University of Minnesota, Department of Statistics, provided statistical advice. Mike Tobin reviewed an earlier draft of the manuscript. Diane DeSteven, Rich Kobe, and three anonymous reviewers spent considerable time on the manuscript and improved it markedly. Kim Walters spent a lot of time helping with revisions and being patient. John Gerlach and Cleo Lajzerowicz also helped with revisions. Support for this study was provided by the National Science Foundation.

\section{Literature Cited}

Armstrong, D. P., and M. Westoby. 1993. Seedlings from large seeds tolerate defoliation better: a test using phylogenetically independent contrasts. Ecology 74:1092-1100.

Augspurger, C. K. 1984. Light requirements of neotropical tree seedlings: a comparative study of growth and survival. Journal of Ecology 72:777-795.

Baker, F. S. 1945. Effects of shade upon coniferous seedlings 
grown in nutrient solutions. Journal of Forestry 43:428435.

Baker, F. S. 1949. A revised shade tolerance table. Journal of Forestry 47:179-181.

Bancroft, T. A. 1964. Analyses and inferences for incompletely specified models involving the use of preliminary tests of significance. Biometrics 20:427-442.

Barnes, B. V., and W. H. Wagner. 1996. Michigan trees: a guide to the trees of Michigan and the Great Lakes region. The University of Michigan Press, Ann Arbor, Michigan, USA.

Barnes, B. V., D. R. Zak, S. R. Denton, and S. H. Spurr. 1998. Forest ecology. Fourth edition. John Wiley and Sons, New York, New York, USA.

Björkman, O. 1981. Responses to different quantum flux densities. Pages 57-107 in O. L. Lange, P. S. Nobel, C. B Osmond, and H. Ziegler, editors. Encyclopedia of plant physiology, Volume 12A. Plant physiological ecology I. Springer-Verlag, New York, New York, USA.

Burns, R. M., and B. H. Honkola. 1990. Silvics of North America. Volumes 1 and 2 (Agricultural Handbook 654). United States Department of Agriculture, Washington D.C., USA.

Canham, C. D., A. R. Berkowitz, V. R. Kelly, G. M. Lovett, S. M. Ollinger, and J. Schnurr. 1996. Biomass allocation and multiple resource allocation in tree seedlings. Canadian Journal of Forest Research 26:1521-1530.

Canham, C. D., J. S. Denslow, W. J. Platt, J. R. Runkle, T. A. Spies, and P. S. White. 1990. Light regimes beneath closed canopies and tree-fall gaps in temperate and tropical forests. Canadian Journal of Forest Research 20:620-631.

Chapin, F. S., III, E. D. Schultze, and H. A. Mooney. 1990. The ecology and economics of storage in plants. Annual Review of Ecology and Systematics 21:423-447.

Cole, D. W. 1981. Nitrogen uptake and translocation in forest ecosystems. Pages 219-232 in F. E. Clark and T. H. Rosswall, editors. Nitrogen cycling in terrestrial ecosystems: processes, ecosystem strategies and management strategies. Ecological Bulletins-NFR 33. Swedish Natural Science Research Council. Stockholm, Sweden.

Coley, P. D. 1988. Effects of plant growth rate and leaf lifetime on the amount and type of anti-herbivore defense. Oecologia 74:531-536.

Cornelissen, J. H. C., P. Castro-Diez, and R. Hunt. 1996. Seedling growth, allocation and leaf attributes in a wide range of woody plant species and types. Journal of Ecology 84:755-765.

Ellsworth, D. S., and P. B. Reich. 1992. Leaf mass per area, nitrogen-content and photosynthetic carbon gain in Acer saccharum seedlings in contrasting forest light environments. Functional Ecology 6:423-435.

Foster, S. A. 1986. On the adaptive value of large seeds for tropical moist forest trees: a review and synthesis. Botany Review 52:260-299.

Foster, S. A., and C. H. Janson. 1985. The relationship between seed size and establishment conditions in tropical woody plants. Ecology 66:773-780.

Fox, G. A. 1993. Failure time analysis: emergence, flowering, survivorship, and other waiting times. Chapter 12 in S. M. Scheiner and J. Gurevitch, editors. Design and analysis of ecological experiments. Chapman and Hall, New York, New York, USA.

Givnish, T. J. 1988. Adaptation to sun and shade: a wholeplant perspective. Australian Journal of Plant Physiology 15:63-92.

Grime, J. P., and D. W. Jeffery. 1965. Seedling establishment in vertical gradients of sunlight. Journal of Ecology 53: $621-642$

Grubb, P. J., and D. F. R. P. Burselem. 1998. Mineral nutrient concentrations as a function of seed size within seed crops: implications for competition among seedlings and defence against herbivory. Journal of Tropical Ecology. 14:177185

Grubb, P. J., W. G. Lee, J. Kollmann, and J. B. Wilson. 1996. Interaction of irradiance and soil nutrient supply on growth of seedlings of ten European tall-shrub species and Fagus sylvatica. Journal of Ecology 84:827-840.

Grubb, P. J., and D. J. Metcalfe. 1996. Adaptation and inertia in the Australian tropical lowland rain-forest flora: contradictory trends in intergeneric and intrageneric comparisons of seed size in relation to light demand. Functional Ecology 10:512-520.

Hutchinson, T. C. 1967. Comparative studies of the ability of species to withstand prolonged periods of darkness. Journal of Ecology 55:291-299.

Jackson, R. B., and M. M. Caldwell. 1993. The scale of nutrient heterogeneity around individual plants and its quantification with geostatistics. Ecology 74:612-614.

Kalbfleish, J. D., and R. L. Prentice. 1980. The statistical analysis of failure time data. John Wiley and Sons, New York, New York, USA.

Kitajima, K. 1994. Relative importance of photosynthetic traits and allocation patterns as correlates of seedling shade tolerance of 13 tropical trees. Oecologia 98:419-428.

Kitajima, K. 1996. Ecophysiology of tropical tree seedlings. Pages 559-597 in S. S. Mulkey, R. L. Chazdon, and A. P. Smith, editors. Tropical forest plant ecophysiology. Chapman \& Hall, New York, New York, USA.

Kobe, R. K. 1996. Intraspecific variation in sapling mortality and growth predicts geographic variation in forest composition. Ecological Monographs 66:181-201.

Kobe, R. K. 1997. Carbohydrate allocation as a basis of interspecific variation in sapling survivorship and growth. Oikos 80:226-233.

Kobe, R. K., and K. D. Coates. 1997. Models of sapling mortality as a function of growth to characterize interspecific variation in shade tolerance of eight tree species of northwestern British Columbia. Canadian Journal of Forest Research 27:227-236.

Kobe, R. K., S. W. Pacala, J. A. Silander, and C. D. Canham. 1995. Juvenile tree survivorship as a component of shade tolerance. Ecological Applications 3:517-532.

Lambers, H., and H. Poorter. 1992. Inherent variation in growth rate between higher plants: a search for physiological causes and ecological consequences. Advances in Ecological Research 23:187-261.

Latham, R. E. 1992. Co-occurring tree species change rank in seedling performance with resources varied experimentally. Ecology 73:2129-2144.

Leishman, M. R., and M. Westoby. 1994. The role of large seed size in shaded conditions: experimental evidence. Functional Ecology 8:205-214.

Loach, K. 1967. Shade tolerance in tree seedlings. I. Leaf photosynthesis and respiration in plants raised under artificial shade. New Phytologist 66:607-621.

Loach, K. 1970. Shade tolerance in tree seedlings. II. Growth analysis of plants raised under artificial shade. New Phytologist 69:273-286.

Maranon, T., and P. J. Grubb. 1993. Physiological basis and ecological significance of the seed size and significance of the seed size and relative growth rate relationship in Mediterranean annuals. Functional Ecology 7:591-599.

Marquis, D. A. 1975. Seed storage and germination under northern hardwood forests. Canadian Journal of Forest Research 5:478-484.

Metcalf, D. J., and P. J. Grubb. 1995. Seed mass and light requirement for regeneration in south-east Asian rain forest. Canadian Journal of Botany 73:817-826.

Milberg, P., M. A. Perez-Fernandez, and B. P. Lamont. 1998. Seedling growth response to added nutrients depends on 
seed size in three woody genera. Journal of Ecology 86: 624-632.

Molofsky, J., and C. K. Augspurger. 1992. The effect of leaf litter on early seedling establishment in a tropical forest. Ecology 73:68-77.

Neter, J., and W. Wasserman. 1974. Applied linear statistical models. Richard D. Irwin, Inc., Homewood, Illinois, USA.

Osunkoya, O. O., J. E. Ash, M. S. Hopkins, and A. W. Graham. 1994. Influence of seed size and seedling ecological attributes on shade tolerance of rain-forest tree species in northern Queensland. Journal of Ecology 82:149-163.

Pacala, S. W., C. D. Canham, J. Saponara, J. A. Silander Jr., R. K. Kobe, and E. Ribbens. 1996. Forest models defined by field measurements. II. Estimation, error analysis, and dynamics. Ecological Monographs 66:1-43.

Pacala, S. W., C. D. Canham, J. A. Silander, and R. K. Kobe. 1994. Sapling growth as a function of resources in a north temperate forest. Canadian Journal of Forest Research 24: $2172-2183$.

Peace, W. J. H., and P. J. Grubb. 1982. Interaction of light and mineral nutrient supply in the growth of Impatiens parviflora. New Phytologist 90:127-150.

Phares, R. E. 1971. Growth of red oak (Quercus rubra L.) in relation to light and nutrients. Ecology 52:669-672.

Pompa, J., and F. Bongers. 1988. The effect of canopy gaps on growth and morphology of seedlings of rainforest species. Oecologia 75:625-632.

Poorter, H., and A. Van Der Werf. 1998. Is inherent variation in RGR determined by LAR at low light and by NAR at high light? Pages 309-336 in H. Lambers, H. Poorter, and M. M. I. Van Vuuren, editors. Inherent variation in plant growth. Physiological mechanisms and ecological consequences. Backhuys Publishers, Leiden, Netherlands.

Reich, P. B., M. G. Tjoelker, M. B. Walters, D. W. Vanderklein, and C. Buschena. 1998. Close association of RGR, leaf and root morphology, seed mass and shade tolerance in seedlings of nine boreal tree species grown in high and low light. Functional Ecology 12:327-338.

Reich, P. B., M. B. Walters, and D. S. Ellsworth. 1992. Leaf lifespan in relation to leaf plant and stand characteristics among diverse ecosystems. Ecological Monographs 62: 365-392.

Salisbury, E. J. 1942. The reproductive capacity of plants: studies in quantitative biology. Bell, London, UK.

Saverimuttu, T., and M. Westoby. 1996. Seedling longevity under deep shade in relation to seed size. Journal of Ecology 84:681-690.
Shipley, B., and R. H. Peters. 1990. The allometry of seed weight and seedling relative growth rate. Functional Ecology 4:523-529.

Steinbauer, G. P. 1932. Growth of tree seedlings in relation to light intensity and concentration of nutrient solution. Plant Physiology 7:742-745.

Swanborough, P., and M. Westoby. 1996. Seedling relative growth rate and its components in relation to seed size: phylogenetically independent contrasts. Functional Ecology 10:176-184.

Veenendaal, E. M., M. D. Swaine, R. T. Lecha, M. F. Walsh, I. K. Abebrse, and K. Owusu-Afriyie. 1996. Responses of West African forest tree seedlings to irradiance and soil fertility. Functional Ecology 10:501-511.

Vitousek, P. M., P. M. Matson, and K. Van Cleve. 1989. Nitrogen availability and nitrification during succession: primary, secondary and old-field series. Pages 161-171 in M. Clarholm and L. Bergstrom, editors. Ecology of arable land. Kluwer, Dordrecht, Netherlands.

Walters, M. B., and C. B. Field. 1987. Photosynthetic light acclimation in two rainforest Piper species with different ecological amplitudes. Oecologia 72:449-456.

Walters, M. B., E. L. Kruger, and P. B. Reich. 1993a. Relative growth rate in relation to physiological and morphological traits for northern hardwood seedlings: species, light environment and ontogenetic considerations. Oecologia 96: 219-231.

Walters, M. B., E. L. Kruger, and P. B. Reich. 1993b. Growth, biomass distribution and $\mathrm{CO}_{2}$ exchange of northern hardwood seedlings in high and low light: relationships with successional status and shade tolerance. Oecologia 94:716.

Walters, M. B., and P. B. Reich. 1996. Are shade tolerance, survival, and growth linked? Low light and nitrogen effects on hardwood seedlings. Ecology 77:841-853.

Walters, M. B., and P. B. Reich. 1997. Growth of Acer saccharum seedlings in deeply shaded understories of northern Wisconsin: effects of nitrogen and water availability. Canadian Journal of Forest Research 27:237-247.

Walters, M. B., and P. B. Reich. 1999. Low-light carbon balance and shade tolerance in the seedlings of woody plants: do winter deciduous and broad-leaved evergreen species differ? New Phytologist 143:143-154.

Walters, M. B., and P. B. Reich. 2000. Tradeoffs in low-light $\mathrm{CO}_{2}$ exchange: a component of variation in shade tolerance among cold-temperate tree seedlings. Functional Ecology, in press. 